\title{
SURVEY INVESTIGASI DISAIN (SID) EMBUNG ALUE SAPI DI KABUPATEN ACEH UTARA
}

\author{
Wesli \\ Jurusan Teknik Sipil Universitas Malikussaleh \\ Email: Wesli@unimal.ac.id
}

DOI:

\begin{abstract}
Abstrak
Untuk meningkatkan kesejahteraan masyarakat, pemerintah memenuhi kebutuhan masyarakat atas sarana dan prasarana public. Salah satu kebutuhan masyarakat adalah tersedianya sumber air irigasi yang memadai untuk mengairi sawah. Embung Alue Sapi mempunyai luas genangan kurang lebih $4 \mathrm{Ha}$ mengairi sawah seluas 500 Ha, Dalam beberapa tahun terakhir embung tersebut tidak lagi berfungsi karena telah terjadi kerusakan sehingga perlu dilakukan perbaikan. Agar pelaksanaan perbaikan dapat sesuai sasaran, maka perlu dilakukan kajian jenis dan tingkat kerusakan sehingga akan diperoleh suatu gambar detail desain melalui Survey Investigasi Disain (SID). Tujuan investigasi disain untuk mengetahui kelayakan embung dalam melayani ketersediaan air persawahan bagi masyarakat. Debit kebutuhan air sebesar $0.65 \mathrm{~m}^{3} / \mathrm{det}$, hal ini lebih kecil dari debit periode ulang 2 tahunan sebesar $0,784 \mathrm{~m}^{3} / \mathrm{det}$, Untuk periode ulang 5 tahunan sebesar $1,036 \mathrm{~m}^{3} / \mathrm{det}$, periode ulang 10 tahunan sebesar $1,203 \mathrm{~m}^{3} /$ det dan periode ulang 25 tahunan sebesar $1,413 \mathrm{~m}^{3} /$ det. Hal ini menunjukkan bahwa potensi air pada embung Alue Sapi cukup memadai, terjadinya masalah tidak berfungsinya embung disebabkan oleh kerusakan pada bagian dinding bangunan bendung, kerusakan pada pintu pembagi dan kurangnya kapasitas tampungan embung.
\end{abstract}

Kata kunci: Investigasi, disain bangunan embung.

\begin{abstract}
To improve the welfare of the community, the government meets the needs of the community for public facilities and infrastructure. One of the needs of the community is the availability of adequate sources of irrigation water to irrigate rice fields. Alue Sapi embankment has a pool area of approximately 4 ha irrigating 500 hectares of rice fields. In the last few years the reservoir has no longer functioned because of damage so it needs to be repaired. In order for the implementation of repairs to be in accordance with the target, it is necessary to study the type and level of damage so that a detailed design image will be obtained through the Design Investigation Survey (SID). The purpose of the design investigation is to determine the feasibility of a reservoir in serving the availability of paddy water for the community. Discharge of water needs is $0.65 \mathrm{~m} 3 / \mathrm{sec}$, this is less than the annual 2-period return discharge of $0.784 \mathrm{~m} 3 / \mathrm{sec}$, for an annual 5-year return period of $1.036 \mathrm{~m} 3 / \mathrm{sec}$, a 10-year return period of $1.203 \mathrm{~m} 3 / \mathrm{sec}$ and a 25 -year return period amounting to $1,413 \mathrm{~m} 3 / \mathrm{sec}$. This shows that the water potential in the Alue Sapi reservoir is sufficient, the problem of the malfunctioning of the dam is caused by damage to the walls of the dam building, damage to the divider door and lack of reservoir capacity.
\end{abstract}

Keywords: Investigation, design of reservoir buildings. 


\section{Latar Belakang}

Pemerintah Daerah melakukan pelayanan kepada masyarakatnya dalam memenuhi kebutuhan masyarakat atas sarana dan prasarana publik dengan sasaran akhir meningkatkan pendapatan masyarakat sehingga mempunyai daya beli yang tinggi. Salah satu kebutuhan masyarakat mendukung kegiatan perekonomian suatu kawasan adalah tersedianya sumber air irigasi yang memadai.

Embung merupakan salah satu tipe bangunan utama yang diterapkan pada daerah yang kemampuan sumber airnya relatif kecil. Bangunan ini diharapkan dapat menampung kelebihan air saat musim hujan, sehingga nantinya dapat digunakan di musim kering (Soedibyo, 1987). Ketelitian pada tahap perencanaan dan kesesuaian dalam penerapan pola operasi, diharapkan nantinya Embung mampu menyediakan air untuk irigasi dan air baku bagi penduduk.

Embung Alue Sapi terletak di kecamatan Banda Baro kabupaten Aceh Utara mempunyai luas genangan kurang lebih $4 \mathrm{Ha}$ mengairi sawah seluas $500 \mathrm{Ha}$, Kebutuhan air untuk mengairi sawah sebesar $0,65 \mathrm{~m}^{3} /$ det. Dalam beberapa tahun terakhir ini embung tersebut tidak lagi berfungsi karena telah terjadi kerusakan sehingga perlu dilakukan perbaikan. Agar pelaksanaan perbaikan dapat sesuai sasaran, maka perlu dilakukan kajian jenis dan tingkat kerusakan sehingga akan diperoleh suatu gambar detail desain. Tujuan investigasi disain untuk mengetahui secara concept paper dan secara akademis tentang kelayakan embung dalam melayani ketersediaan air persawahan bagi masyarakat.

\section{Metode Penelitian}

\subsection{Inventarisasi Lapangan dan Pengumpulan Data}

Langkah-langkah yang harus ditempuh untuk mendapatkan data dan informasi adalah sebagai berikut:

- Melakukan survey, penyelidikan dan penelitian langsung ke lapangan.

- Mencari, mengumpulkan, menginventarisasi dan mengelompokkan data sehingga susunannya akan lebih praktis, sederhana dan mudah diinterpretasikan.

- Mencatat kekurangan data yang dibutuhkan dan mencocokkan, mengevaluasi, menguji data baik di studio atau dilapangan yang berupa tabel/daftar, diagram dan peta.

- Mengolah dan menganalisis data yang telah tersusun.

\subsection{Pengukuran Topografi}

Langkah-langkah yang harus ditempuh untuk mendapatkan data dan informasi adalah sebagai berikut:

- Melakukan pekerjaan pemetaan topografi harus mengacu pada Standard Perencanaan Irigasi (PT-02) dengan rincian pemetaan daerah lokasi Embung dan Bangunan fasilitasnya skala $1: 500$ atau $1: 1000$

- Pengukuran Topografi

Gambar-gambar hasil pengukuran dan perencanaan dibuat dengan format Digitalisasi AutoCAD, diformat pada kertas A3, untuk print out pada kertas merupakan format standard sesuai dengan skala. 
Perencanaan potongan memanjang dan potongan melintang diplot pada gambar hasil pengukuran lapangan. Untuk penggambaran bangunan dipakai skala sebagai berikut:

- Denah 1:100, potongan-potongan 1:50, Detail 1:10 atau 1:20.

- Ukuran-ukuran garis, legenda, penulisan angka ukuran, penomoran, arsiran dan keterangan-keterangan lainnya yang digunakan pada penggambaran mengacu pada ketentuan yang berlaku

\section{Hasil dan Pembahasan}

Embung Alue Sapi berada pada titik koordianat N5 11287 E96 58220 dengan luas area embung kurang lebih 0,48741 Ha, Letak geografi Embung Alue Sapi selengkapnya seperti diperlihatkan pada Gambar 1

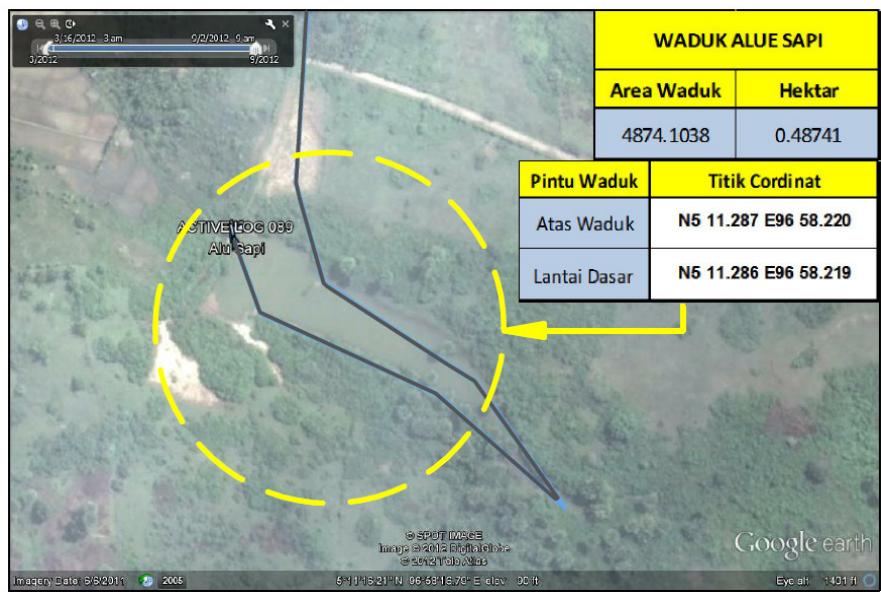

Gambar 1 Letak Geografi Embung Alue Sapi

\subsection{Kependudukan, Potensi Daerah}

Menurut Bappeda Aceh Utara (2011), struktur penduduk berdasarkan jenis kelamin di wilayah survey memiliki populasi yang hampir sama dengan besaran 12.010 jiwa laki-laki dan 12.482 jiwa perempuan. Jumlah penduduk di kedua daerah sebesar 24.492 jiwa dengan perincian di kecamatan Nisam terdiri dari 8.469 jiwa laki-laki dan 8.646 jiwa perempuan dan total penduduk 17.115 jiwa sementara di kecamatan Banda Baro terdiri dari 3.541 jiwa laki-laki dan 3.836 jiwa perempuan dengan total penduduk 7.377 jiwa. Tingkat pertumbuhan penduduk rata-rata di kecamatan Nisam 1,08\% per-tahun dan di kecamatan Banda Baro tingkat pertumbuhan penduduk $0,24 \%$ per-tahun. Struktur penduduk selengkapnya diperlihatkan pada Tabel 1

Tabel 1 Struktur Penduduk di Wilayah Survey

\begin{tabular}{|c|c|c|c|}
\hline Penduduk & Laki-laki & Perempuan & Jumlah \\
\hline Nisam & 8.469 & 8.646 & 17.115 \\
\hline Banda Baro & 3.541 & 3.836 & 7.377 \\
\hline Jumlah & 12.010 & 12.482 & 24.492 \\
\hline
\end{tabular}


Potensi di wilayah survey terdiri dari potensi pertanian, potensi perkebunan dan potensi peternakan. Pada potensi pertanian hampir semua komoditi pertanian yang dihasilkan oleh kabupaten Aceh Utara ada di wilayah survey, demikian pula halnya dengan komoditi perkebunan dan peternakan. Pertanian merupakan salah satu sektor prioritas pembangunan di kabupaten Aceh Utara. Pembangunan tersebut dilakukan melalui pengembangan sistem irigasi sebagai penyediaan, pengaturan dan pembuangan untuk menunjang pertanian rakyat. Potensi terbesar adalah potensi tanaman padi dengan luas tanam 3.469 Ha dan luas panen 3.456 Ha yang menghasilkan produksi sebesar 26.604,29 ton di kecamatan Nisam. Sementara di kecamatan Banda Baro kondisi potensi terbesar juga pada komoditi tanaman padi dengan luas tanam sebesar 1.694 Ha dan luas panen 1.484 Ha yang mampu menghasilkan produksi padi 7.026,74 ton. Disamping komoditi padi jiga mempunyai potensi pada komoditi kedelai. Potensi pertanian di wilayah survey selengkapnya diperlihatkan pada Tabel 2

Tabel 2 Potensi Pertanian di wilayah Survey

\begin{tabular}{lrrrrrr}
\hline \multirow{2}{*}{ Komoditi } & \multicolumn{2}{c}{ Kecamatan Nisam } & \multicolumn{3}{c}{ Kecamatan Banda Baro } \\
\cline { 2 - 7 } & $\begin{array}{c}\text { Luas } \\
\text { Tanam } \\
\text { (Ha) }\end{array}$ & $\begin{array}{c}\text { Luas } \\
\text { Panen } \\
\text { (Ha) }\end{array}$ & $\begin{array}{c}\text { Produksi } \\
\text { (ton) }\end{array}$ & $\begin{array}{c}\text { Tuas } \\
\text { Tanam } \\
\text { (Ha) }\end{array}$ & $\begin{array}{c}\text { Luas } \\
\text { Panen } \\
\text { (Ha) }\end{array}$ & $\begin{array}{c}\text { Produksi } \\
\text { (ton) }\end{array}$ \\
\hline Padi & 3.469 & 3.456 & $26.604,29$ & 1.694 & 1.484 & $7.026,74$ \\
Kedelai & 258 & 237 & 376,36 & 33 & 22 & 34,1 \\
Jagung & 102 & 95 & 314,93 & 60 & 14 & 46,34 \\
Kacang Tanah & 30 & 30 & 58,08 & 83 & 85 & 163,54 \\
Kacang Hijau & 6 & 6 & 9,12 & 5 & 5 & 7,5 \\
Ubi Kayu & 8 & 8 & 172,14 & 43 & 43 & 924,72 \\
Kacang Panjang & 29 & 34 & 181,6 & 36 & 55 & 284,4 \\
Cabe & 11 & 53 & 213,9 & 12 & 25 & 119,2 \\
Tomat & 0 & 0 & 0 & 7 & 8 & 94,5 \\
Terong & 0 & 10 & 91,5 & 5 & 6 & 73,5 \\
Ketimun & 23 & 33 & 318,5 & 9 & 17 & 175 \\
Bayam & 33 & 33 & 148,8 & 17 & 16 & 74,6 \\
Semangka & 5 & 5 & 57 & 5 & 5 & 75 \\
Kangkung & 27 & 27 & 136,5 & 3 & 3 & 31 \\
Cabe Rawit & 9 & 16 & 75,2 & 11 & 24 & 139 \\
\hline \multicolumn{2}{c}{} & Sumber: Bappeda Aceh Utara $(2011)$ & &
\end{tabular}

Sumber: Bappeda Aceh Utara (2011)

Pada wilayah survey memiliki lahan yang luas untuk melakukan pembangunan di bidang peternakan baik berupa ternak besar, ternak kecil maupun unggas. Produksi ternak sapi di kecamatan Nisam rata-rata sebesar 7695 ekor, di kecamatan Banda Baro produksi ternak sapi rata-rata sebesar 4.084 ekor. Sementara produksi ternak kerbau sebesar 1.578 ekor di kecamatan Nisam dan sebesar 702 ekor di kecamatanm Banda Baro. Untuk produksi kambing di kecamatan Nisam rata-rata sebesar 4.605 ekor dan di kecamatan Banda Baro sebesar 3.961 ekor. Demikian halnya dengan produksi domba di kecamatan Nisam sebesar 3.093 ekor sementara di kecamatan Banda Baro sebesar 1.339 ekor. Produksi unggas terdiri dari ayam buras sebesar 18.772 ekor di kecamatan 
Nisam dan 13.960 ekor di kecamatan Banda Baro sementara ayam pedaging (Broiler) sebesar 20.655 ekor di kecamatan Banda Baro dan kecamatan Nisam tidak menghasilkan ayam broiler. Produksi itik di kecamatan Nisam sebesar 15.317 ekor dan di kecamatan Banda Baro sebesar 9.441 ekor. Potensi Peternakan selengkapnya diperlihatkan pada Tabel 3

Tabel 3 Potensi Peternakan di wilayah Survey

\begin{tabular}{lcc}
\hline Komoditi & $\begin{array}{c}\text { Kecamatan Nisam } \\
\text { Produksi (ekor) }\end{array}$ & $\begin{array}{c}\text { Kecamatan Banda Baro } \\
\text { Produksi (ekor) }\end{array}$ \\
\hline Sapi & $7.695,00$ & $4.084,00$ \\
Kerbau & $1.578,00$ & 702,00 \\
Kambing & $4.605,00$ & $3.961,00$ \\
Domba & $3.093,00$ & $1.339,00$ \\
Ayam Buras & $18.772,00$ & $13.960,00$ \\
Ayam Broiler & 0,00 & $20.655,00$ \\
Itik & $15.317,00$ & $9.441,00$ \\
\hline
\end{tabular}

Sumber: Bappeda Aceh Utara (2011)

\subsection{Pelaksanaan Survey dan Investigasi}

Hasil survey merupakan dasar untuk melakakukan perencanaan. Pengumpulan data juga dilakukan melalui wawancara dengan masyarakat sebagai masukan dalam merumuskan masalah dan penentuan solusinya (Direktorat Jenderal Pengairan, 1986). Dari hasil survey dan investigasi awal telah diperoleh gambaran embung dan permasalahan yang terjadi baik pada masa yang lalu maupun kondisi saat ini.

Embung Alue Sapi berada di kecamatan Banda Baro dengan luas embung kurang lebih $1 \mathrm{Ha}$ dan luas persawahan yang dilayani kurang lebih $500 \mathrm{Ha}$. Persawahan yang dilayani berada dibeberapa desa yaitu Gampong Ulee Nye, Gampong Cot Jabee, Gampong Payah Dua dan sebagian Gampong Sangkelan.

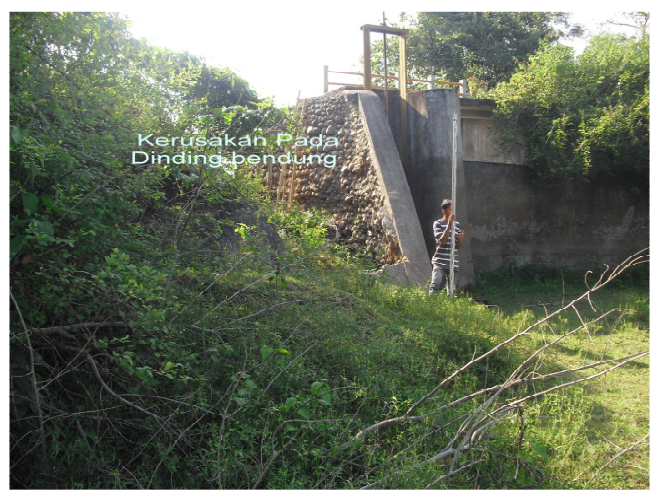

Gambar 2 Lokasi Kerusakan Dinding Bendung

Sumber air Embung Alue Sapi mutlak hanya mengharapkan dari air hujan yang akan ditampung oleh embung dan kondisi saat ini tidak berfungsi karena terjadi kerusakan pada bagian bendung yang patah sebagian. Disamping itu juga terjadi kerusakan pada pintu air akibat terjadinya korosi. Tidak berfungsinya embung sudah berlangsung kurang lebih selama 3 tahun terakhir. Sebelumnya 
ketika embung masih berfungsi pada dasarnya sudah ada permasalahan yaitu kecilnya kapasitas daya tampung embung di mana luas dasar embung yang terlalu kecil sehingga pada area persawahan selalu terjadi kekurangan air yang sering berakibat pada kegagalan panen. Selama embung tidak berfungsi, masyarakat telah melakukan upaya secara mandiri untuk dapat memfungsikan kembali embung tersebut dengan cara perbaikan pintu embung dan memperbaiki dinding bendung yang rusak melalui upaya memasukkan tanah timbun kedalam karung dan bambu yang diletakkan pada dinding embung yang patah namun masih terjadi kebobolan pada bagian tersebut

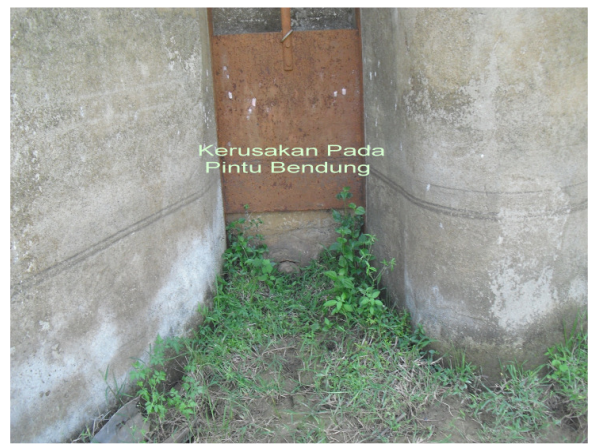

Gambar 3 Kerusakan Pada Pintu Bendung

Pada Gambar 3 memperlihatkan bahwa kondisi pinti embung yang sudah tidak memadai dan terjadi korosi (karat) sehingga pintu air sulit untuk dinaikturunkan dalam pengaturan air persawahan. Disamping itu kondisi dimulut pintu belum adanya lantai keluaran air sehingga banyak ditumbuhi rumputrumputan dan besar kemungkinan terjadi infiltrasi (penyerapan air ke dalam tanah).

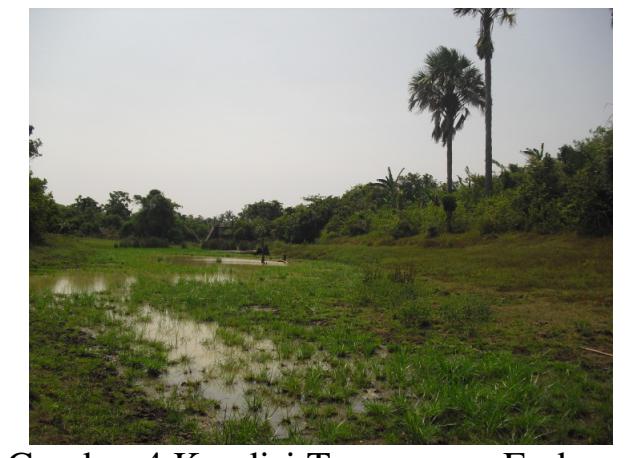

Gambar 4 Kondisi Tampungan Embung

\subsubsection{Topografi Embung}

Hasil pengukuran topografi Embung memperlihatkan bahwa luasan permukaan basah dan volume tampungan pada masing-masing elevasi masih belum memadai. Elevasi terendah diambil 1 meter dibawah elevasi dasar saluran di mana elevasi dasar saluran pada +27 dan elevasi dasar waduk pada +28 yang nantinya menjadi tampungan mati (dead load) dengan luasan permukaan basah $81,02 \mathrm{~m}^{2}$ dan kapasitas tampungan embung 40,51 $\mathrm{m}^{3}$. Elevasi Luas permukaan basah maksimal pada elevasi +33 (tampungan 
embung penuh) seluas $12.235,73 \mathrm{~m}^{2}$ dan pada kondisi eksisting diperoleh kapasitas tampung embung hanya sebesar 35.845,96 $\mathrm{m}^{3}$. Berdasarkan kondisi ini maka perlu dilakukan penggalian embung untuk meningkatkan daya tampung embung Alue Sapi. Topografi Embung pada kondisi eksisting seperti diperlihatkan pada Gambar 5

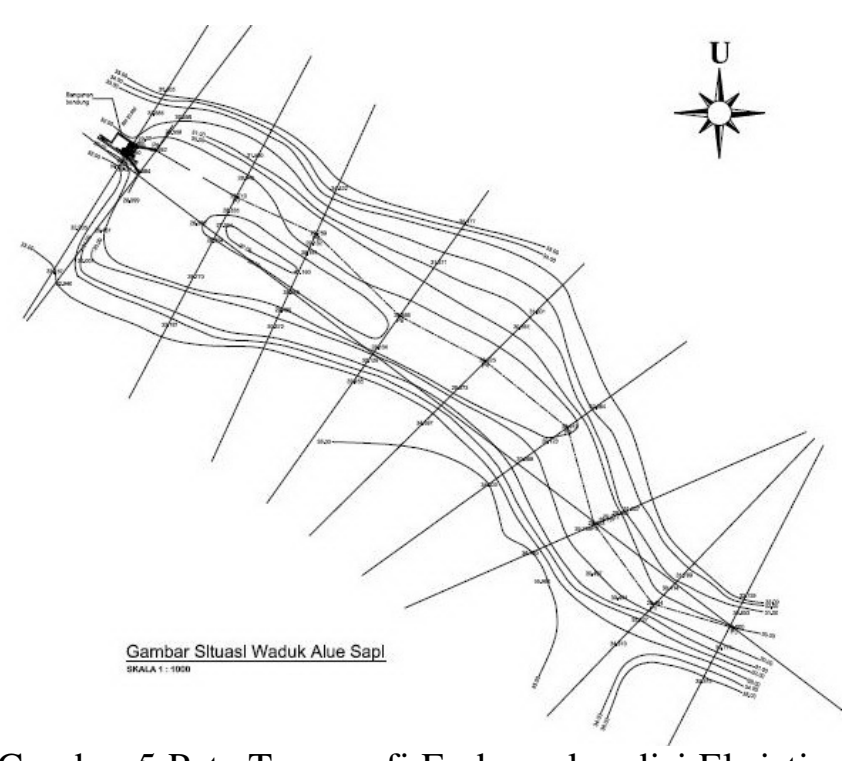

Gambar 5 Peta Topografi Embung kondisi Eksisting

Penggalian dilakukan mulai dari depan bangunan bendung sampai ke cross section titik P3. Perencanaan elevasi pada topografi dari daerah penggalian dalam upaya penambahan kapasitas tampungan embung seperti diperlihatkan pada Gambar 5.2. Sementara cross section masing-masing pada cross section P3, P4, P5, P6, P7 dan P8 dilakukan penggalian pada bagian sisi tebing, hal ini seperti yang diperlihatkan pada masing-masing Gambar 5 dan pada Gambar 6.

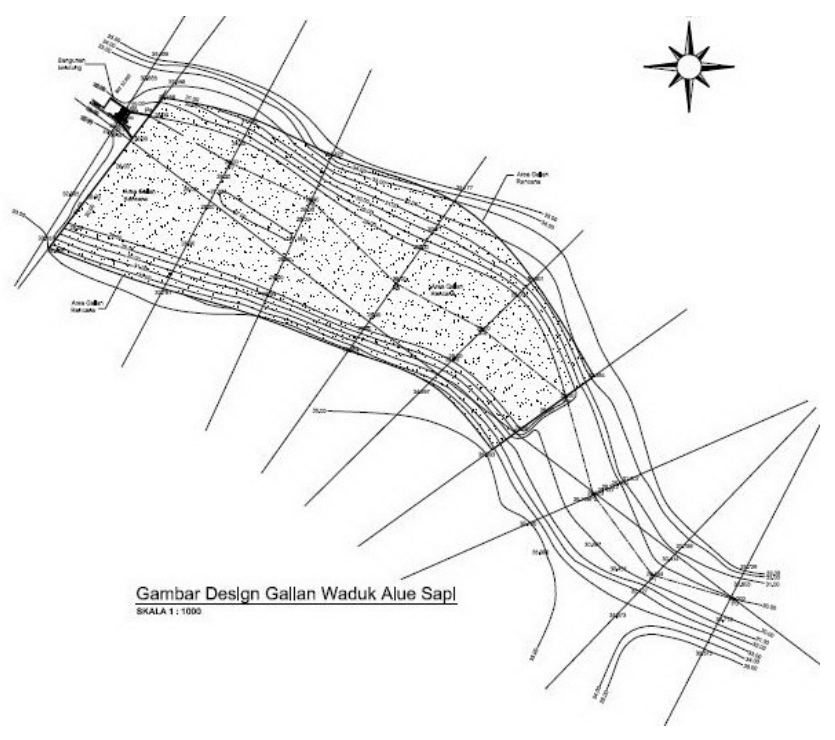


Gambar 6 Peta Topografi Embung Setelah Penggalian

Penggalian yang dilakukan pada Embung pada masing-masing elevasi memberikan tambahan volume air sebagai berikut:

Pada elevasi +27 belum menambah volume air

Pada elevasi +28

Pada elevasi +29

Pada elevasi +30

Pada elevasi +31

Pada elevasi +32 tambahan volume $2.150,25 \mathrm{~m}^{3}$ tambahan volume $5.236,21 \mathrm{~m}^{3}$ tambahan volume $6.805,99 \mathrm{~m}^{3}$ tambahan volume $7.663,91 \mathrm{~m}^{3}$ tambahan volume $8.009,93 \mathrm{~m}^{3}$

Pada elevasi +33 tambahan volume $8.167,72 \mathrm{~m}^{3}$
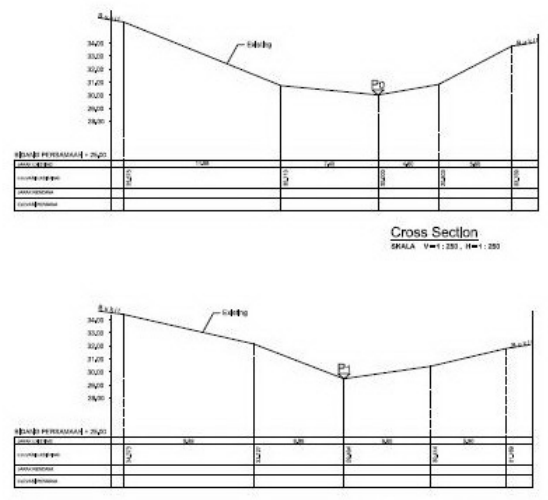

$\frac{\text { Cross Sectlon }}{\text { Wum sol }}=$
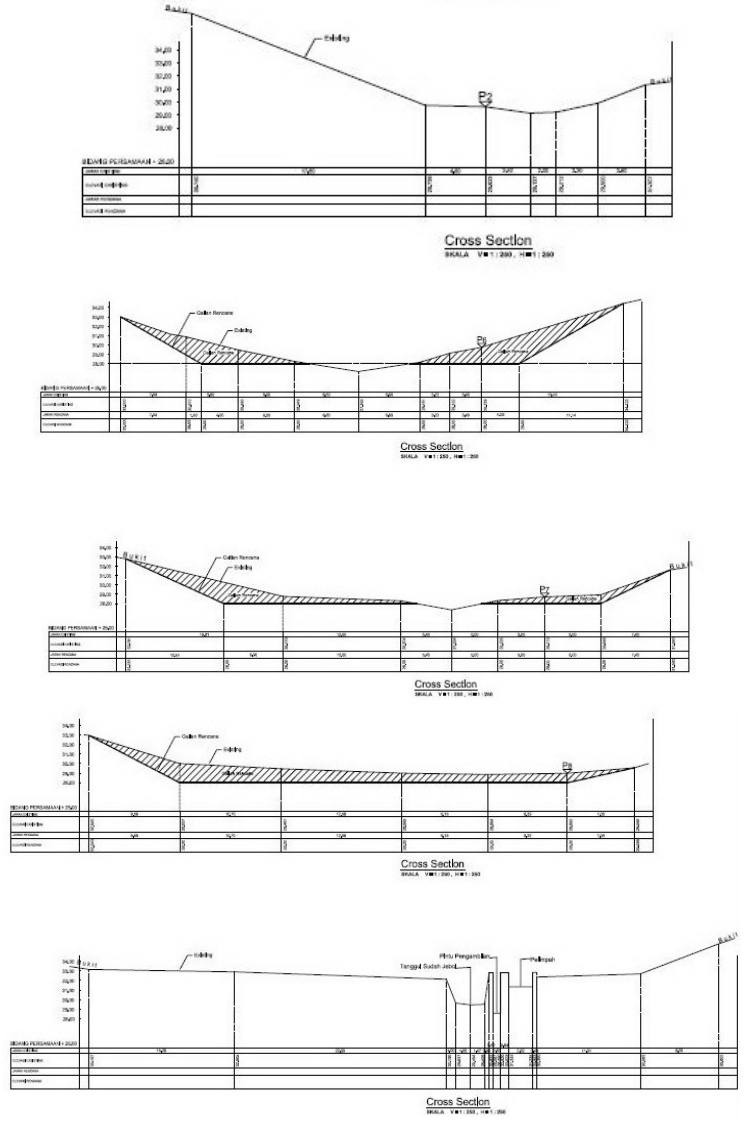

Gambar 7 Elevasi Cross Section Penggalian Embung 
Kondisi luas permukaan embung dan volume tampungan waduk sebelum dan sesudah dilakukan penggalian serta jumlah peningkatan kapasitas tampungan selengkapnya diperlihatkan pada Tabel 4

Tabel 4 Luas Permukaan dan Kapasitas Tampungan Sebelum dan Sesudah Penggalian

\begin{tabular}{|c|c|c|c|c|c|}
\hline \multirow{2}{*}{ Elevasi } & \multicolumn{2}{|c|}{$\begin{array}{c}\text { Sebelum digali / } \\
\text { layer }\end{array}$} & \multicolumn{2}{|c|}{$\begin{array}{c}\text { Sesudah digali / } \\
\text { layer }\end{array}$} & \multirow{2}{*}{$\begin{array}{l}\text { volume air } \\
\text { bertambah } \\
\quad\left(\mathbf{m}^{\mathbf{3}}\right)\end{array}$} \\
\hline & $\begin{array}{l}\operatorname{luas} \\
\left(\mathbf{m}^{2}\right)\end{array}$ & $\begin{array}{c}\text { volume } \\
\left(\mathbf{m}^{3}\right)\end{array}$ & $\begin{array}{l}\text { luas } \\
\left(\mathbf{m}^{2}\right) \\
\end{array}$ & $\begin{array}{c}\text { volume } \\
\left(\mathbf{m}^{3}\right)\end{array}$ & \\
\hline 33 & $12.235,73$ & $11.214,73$ & $12.306,92$ & $11.372,52$ & \\
\hline 32 & $10.193,73$ & $9.405,05$ & $10.438,11$ & 751,08 & 34 \\
\hline 31 & $8.616,38$ & $7.500,46$ & $9.064,04$ & $8.358,38$ & 857,92 \\
\hline 30 & $6.384,54$ & $5.107,59$ & $7.652,71$ & $6.677,38$ & $1.569,79$ \\
\hline 29 & $3.830,65$ & $2.226,22$ & $5.702,05$ & $5.312,17$ & $3.085,95$ \\
\hline 28 & 621,79 & 351,40 & $4.922,29$ & $2.501,66$ & $2.150,25$ \\
\hline 27 & 81,02 & 40,51 & 81,02 & 40,51 & 0,00 \\
\hline Jumlah & & $35.845,96$ & & $44.013,68$ & $8.167,72$ \\
\hline
\end{tabular}

Perhitungan hubungan luas terhadap volume embung didasarkan pada data peta topografi dengan skala 1:1.000 dan beda tinggi kontur $1 \mathrm{~m}$. Cari luas permukaan embung yang dibatasi garis kontur, kemudian dicari volume yang dibatasi oleh 2 garis kontur yang berurutan dengan menggunakan rumus pendekatan volume sebagai berikut (Bangunan Utama KP-02, 1986):

$$
V x=\frac{1}{3} Z\left(F_{y}+F_{x}+\sqrt{F_{y}+F_{x}}\right)
$$

di mana :

$$
\begin{aligned}
& \mathrm{Vx}=\text { volume pada kontur } \mathrm{X}\left(\mathrm{m}^{3}\right) \\
& \mathrm{Z}=\text { beda tinggi antar kontur }(\mathrm{m}) . \\
& \mathrm{Fy}=\text { luas pada kontur } \mathrm{Y}\left(\mathrm{km}^{2}\right) . \\
& \mathrm{Fx}=\text { luas pada kontur } \mathrm{X}\left(\mathrm{km}^{2}\right) .
\end{aligned}
$$

Elevasi dasar saluran yang akan menjadi dasar embung adalah $+27,00 \mathrm{~m}$ sedangkan elevasi permukaan embung penuh air adalah $+33,00 \mathrm{~m}$. Luas embung pada masing-masing elevasi, yaitu:
F27 untuk elevasi $+27,00$
$81,02 \mathrm{~m}^{3}$
F28 untuk elevasi $+28,00$
$621,79 \mathrm{~m}^{3}$
F29 untuk elevasi $+29,00$
$3.830,65 \mathrm{~m}^{3}$
F30 untuk elevasi $+30,00$
$6.384,54 \mathrm{~m}^{3}$
F31 untuk elevasi $+31,00$
$8.616,38 \mathrm{~m}^{3}$
F32 untuk elevasi $+32,00$
$10.193,73 \mathrm{~m}^{3}$
F33 untuk elevasi $+33,00$
$12.235,73 \mathrm{~m}^{3}$

Berdasarkan hasil hitungan terhadap luas permukaan embung dan volume tampungan embung pada masing-masing elevasinya dibuat gambar dalam bentuk Grafik hubugan elevasi, luas embung dan volume tampungan seperti diperlihatkan pada Gambar 8. 


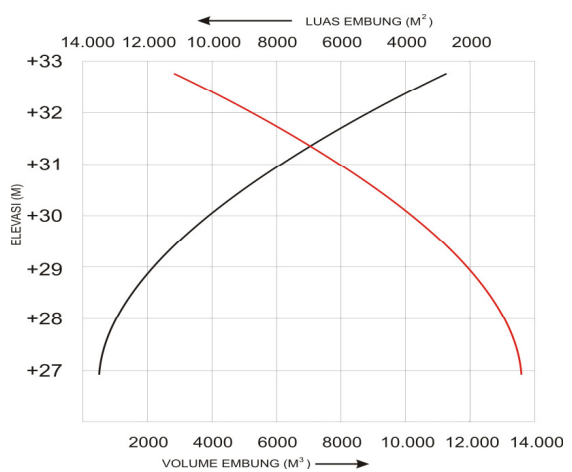

Gambar 8 Grafik Hubungan Elevasi, Luas dan Volume

\subsubsection{Perencanaan Teknis Embung}

Pada embung permasalahan yang terjadi adalah Kapasitas embung tidak memadai untuk mengairi persawahan yang dilayani. Dari analisis hidrologi memperlihatkan bahwa debit periode ulang 2 tahunan sebesar $0,784 \mathrm{~m}^{3} / \mathrm{det}$, Untuk periode ulang 5 tahunan sebesar $1,036 \mathrm{~m}^{3} /$ det, periode ulang 10 tahunan sebesar $1,203 \mathrm{~m}^{3} /$ det dan periode ulang 25 tahunan sebesar $1,413 \mathrm{~m}^{3} /$ det. Hal ini menunjukkan bahwa potensi air pada embung Alue Sapi cukup memadai. Untuk itu perlu dilakukan penggalian pada tampungan embung sehingga daya tampung embung semula $35.845,96 \mathrm{~m}^{3}$ akan menjadi 44.013,68 $\mathrm{m}^{3}$ yang bermakna bahwa terjadi penambahan daya tampung embung sebesar $8.167,72 \mathrm{~m}^{3}$.

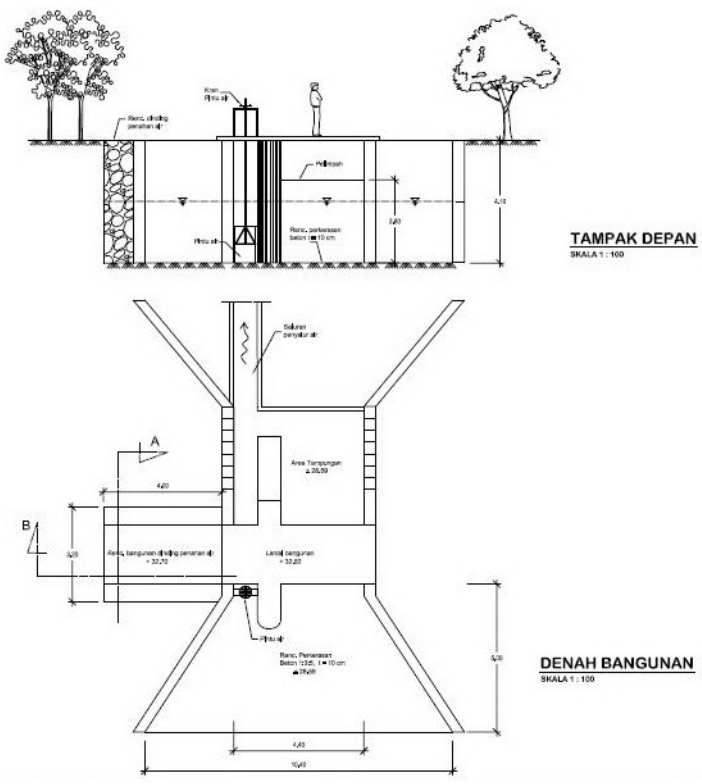

Gambar 9 Perencanaan Bangunan Dinding Bendung Embung

Disamping itu permasalahan lainnya adalah terjadi kerusakan (jebol) dinding bangunan bendung dan kerusakan pada pintu pengaturan sehingga perlu dilakukan perbaikan. Dinding pada bangunan bendung dibuat dengan inti dinding dari beton bertulang dan pada bagian luar diperkuat dengan dinding penahan dari batu kali. Perencanaan pada dinding dan pintu pembagi seperti diperlihatkan pada Gambar 9 dan Gambar 10 serta Gambar 11 

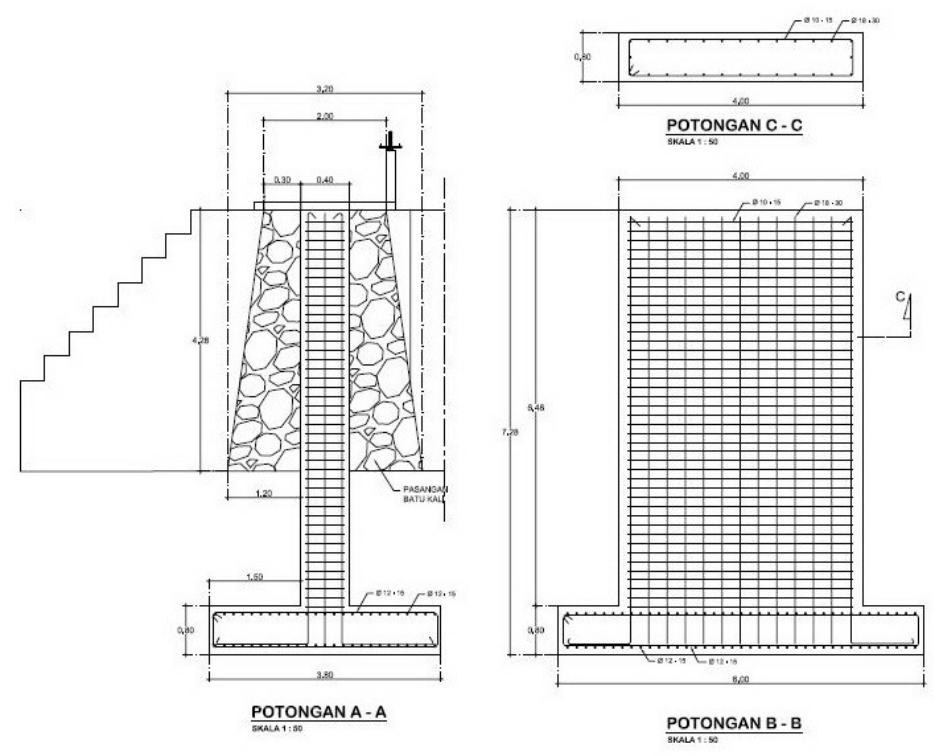

Gambar 10 Perencanaan Penulangan Pada Bangunan Dinding Bendung Embung

Detil desain dinding pada bagian atas inti dinding dengan lebar sebesar 40 $\mathrm{cm}$ dan bagian atas dinding penahan tanah dari batu kali pada masing-masing sisi dengan lebar $30 \mathrm{~cm}$ sehingga lebar bagian atas dinding secara keseluruhan $100 \mathrm{~cm}$ $(1 \mathrm{~m})$. Lebar bawah dinding secara keseluruhan $280 \mathrm{~cm}(2,8 \mathrm{~m})$ dengan panjang dinding $400 \mathrm{~cm}(4 \mathrm{~m})$. Hasil perhitungan penulangan pada bagian inti dinding menggunakan tulangan pokok diameter $18 \mathrm{~mm}$ dengan jarak $30 \mathrm{~cm}$ dan tulangan beugel menggunakan tulangan diameter $10 \mathrm{~mm}$ dengan jarak masing-masing 15 $\mathrm{cm}$

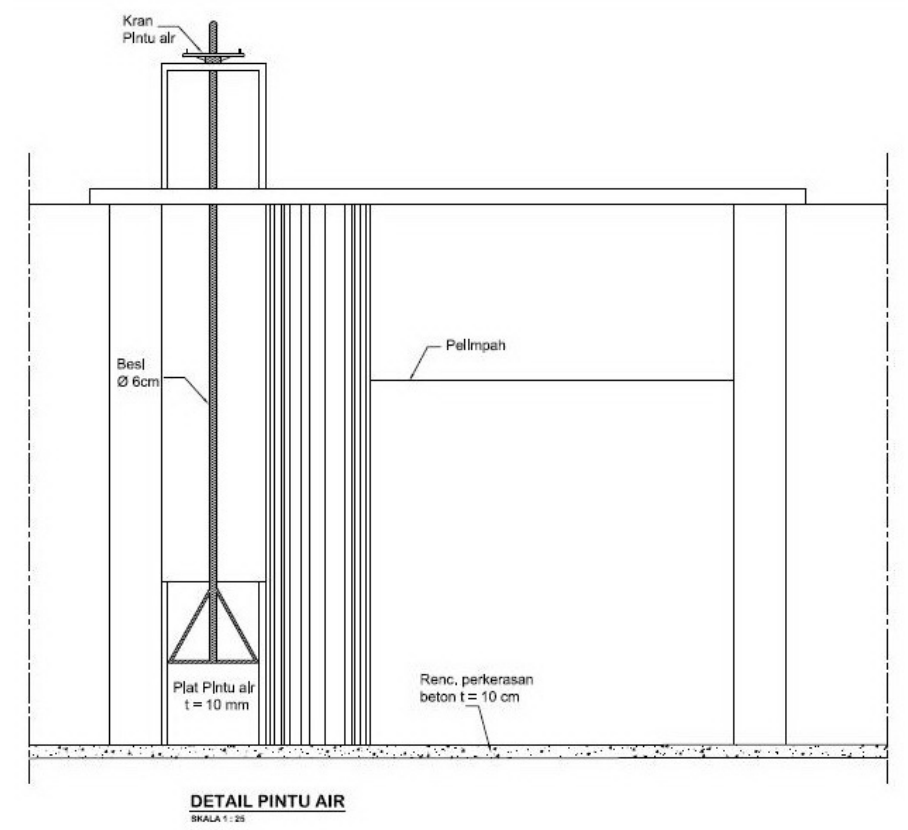

Gambar 11 Perencanaan Pada Pintu Pembagi Bangunan Bendung Embung 


\section{Kesimpulan dan Saran}

\subsection{Kesimpulan}

Kebutuhan air pada Embung Alue Sapi untuk mengairi sawah seluas $500 \mathrm{Ha}$ sebesar $0,65 \mathrm{~m}^{3} /$ det. Hasil analisis hidrologi menggambarkan bahwa debit Periode Ulang 2 tahunan sebesar $0,784 \mathrm{~m}^{3} / \mathrm{det}$, Untuk periode ulang 5 tahunan sebesar $1,036 \mathrm{~m}^{3} /$ det, periode ulang 10 tahunan sebesar $1,203 \mathrm{~m}^{3} /$ det dan periode ulang 25 tahunan sebesar $1,413 \mathrm{~m}^{3} /$ det. Hal ini menunjukkan bahwa kebutuhan air lebih kecil dari ketersediaan air, dan potensi air pada embung Alue Sapi cukup memadai. Terjadinya masalah tidak berfungsinya embung disebabkan oleh kerusakan pada bagian dinding bangunan bendung, kerusakan pada pintu pembagi dan kurangnya kapasitas tampungan embung.

\subsection{Saran}

Embung Alue Sapi, perlu dilakukan perbaikan pada dinding bangunan bendung yang rusak, membuat lantai pada bagian hulu bangunan bendung, Pintu pembagi air harus diganti, perlu dilakukan penggalian pada tampungan embung.

\section{Daftar Kepustakaan}

Bappeda Aceh Utara, 2011, Kabupaten Aceh Utara Dalam Angka, Pemerintah Kabupaten Aceh Utara

Chow, V.T., Maidment, D.R., and Mays, L. W., 1988, Applied Hydrology, Mc Graw Hill Book Company, New York

Direktorat Jenderal Pengairan, 1986, Kriteria Perencanaan Irigasi KP.02, Departemen Pekerjaan Umum

Direktorat Jenderal Pengairan, 1986, Kriteria Perencanaan Irigasi KP.07, Departemen Pekerjaan Umum

Soedibyo, 1987, Teknik Bendungan, Cetakan ke 2, Pradnya Paramita, Jakarta 